\title{
Professor Dr. Marshall Raymond Urist (1914-2001): discoverer of bone formation by induction
}

\author{
Raúl Álvarez-San Martín \\ Centro Médico ABC, Ciudad de México, Mexico
}

\begin{abstract}
Marshall R. Urist was an American orthopedic surgeon who worked in University of California at Los Angeles. His scientific work about bone formation brought to medical science the discovery of a bone growth inductor substance known as bone morphogenetic protein in 1965. The protein today is a recombinant genetically produced substance which helps to regenerate connective tissues and stimulates non specialized cells to transform in to osteoblastic cell lineage. This biographical document about Urist reviews his life, career, classic scientific papers and those landmark contributions to medical science.
\end{abstract}

KEY WORDS: Protein. Bone. Morphogenetic. Formation. Induction.

In 2004, the American Academy of Orthopedic Surgery (AAOS) mentioned that the life of Marshall Urist was an example that clinical research can stimulate significant advances in medical treatment and that, in addition, it can give origin to an entire related industry. His contributions to orthopedics are a legacy that supports the value and application of clinical research to contemporary medical practice; however, but it goes beyond. Urist contributed with a scientific transformation of orthopedic surgery as we see it today, by participating in curricular direction modification after World War II. In 1929 and 1930 full-time orthopedic pathology residences started in the USA at Boston Mayo Clinic, New York Orthopedic Hospital and the New York Hospital for the Ruptured and Crippled (currently Hospital for Special Surgery), with pathology being the only basic science in orthopedics in the USA. As of 1950, other scientific disciplines began to be included in orthopedic hospitals laboratories and departments, but it was until 1954 that the Orthopedic Research Society (ORS) was founded with the purpose to create exclusive interest on scientific research. It was influenced by this society that Marshall Urist, from Los Angeles, became one of the young orthopedist surgeons (together with Andrew Baset in New York, Jonathan Cohen and Henry Mankin in Boston, and Robert D. Ray in Chicago) that revolutionized the discipline, since they occupied full-time posts in basic research and medical services administration from the laboratory, thus combining advanced research with hospital clinical surgery in orthopedics ${ }^{1}$.

Dr. Jeffrey J. Eckardt, being professor and head of the Department of Orthopedic Surgery of the University of California in Los Angeles School of Medicine, stated in 2013 that Marshall R. Urist was a man of vision, of endless energy, insatiable curiosity and overwhelming human compassion². With no doubt, Urist was a visionary; he himself said in 1997 in the Journal of NIH Research that the bone morphogenetic protein was destined to bring bone formation under the control of surgeons before the $20^{\text {th }}$ century was over $^{3}$. On that same year, he also mentioned in a Journal of Bone and Mineral Research editorial that it was the beginning of the molecularization of knowledge on skeletal system development ${ }^{4}$.

\section{Correspondence:}

Raúl Álvarez-San Martín

Campus Observatorio

Torre Donald Mackenzie, Consultorio 111, Sur 136

No. 116

Col. Las Américas, Del. Álvaro Obregón C.P. 01120 , Ciudad de México, México

E-mail: alvarez_sanmartin@yahoo.com.mx
Date of reception: 03-11-2016

Date of acceptance: 03-07-2017

DOI://dx.doi.org/10.24875/GMM.M18000103
Gac Med Mex. 2017;153:861-865

Contents available at PubMed www.gacetamedicademexico.com 
Marshall Raymond Urist was born on June 11, 1914, in Chicago, Illinois, USA, but raised in the rural community of South Haven, in Michigan, in the north of the USA. When he concluded his high-school education, Urist enrolled in the University of Michigan, where he graduated in 1936, to later, in 1937, being able to obtain a Master of Science degree at the University of Chicago, after working in Dr. Franklin Chambers Mc Lean (founder of medical residencies in USA) laboratory. A few years later, in 1941, he obtained his medical degree when graduating from the Johns Hopkins University Medical School, in Baltimore. After completing one year of surgical residency at the Children's Hospital in Baltimore, he enlisted in the US Army, where he was included in war activities of World War II in 1943. In that period, he was assigned to the $22^{\text {nd }}$ General Hospital in Palm Desert, California, with this unit eventually being assigned to England. In England, he served as Chief of Orthopedics, then as Appointed Regional Consultant of the $802^{\text {nd }}$ Hospital Center and at the Orthopedics service of the $92^{\text {nd }}$ General Hospital Division at Frankfurt am Mainz, in Germany ${ }^{5}$.

Subsequently, in 1945, he was assigned to the Pentagon, where one of his assignments took place in the General Surgeon's Office, where he had to record the advances made during World War II with regard to the management of compound fractures of the lower extremity, secondary to combat wounds and accidents in military motor vehicles ${ }^{6-13}$. His works resulted in contributions to the publication of a treatise on the management of compound fractures in charge of Dr. Mather Cleveland, entitled "Orthopedic Surgery in World War II in the European Theater of Operations"8, referring dually to the term "European operating room" as European Theater of Operations (ETO), a zone assigned to American military operations in the European region. For his effort in this period, he received several honors in 1947, such as the Sir Henry Welcome Award for his important contributions to military surgery ${ }^{9}$, a Bronze Star (for merit), and two special citations by General Leonard Heaton and General Dwight D. Eisenhower ${ }^{5}$.

Upon returning from the militia, in the summer of 1946, became a resident at the Massachusetts General Hospital, where he worked with Dr. Smith-Petersen focusing on works on primary hip-replacement surgery ${ }^{13}$. He then completed his medical residency training in orthopedics at Boston Children's Hospital, mainly focusing there on the study of poliomyelitis. At the end of 1947, Urist returned to Chicago for one year to investigate endosteal bone formation under the influence of estrogen, in addition to serving as an

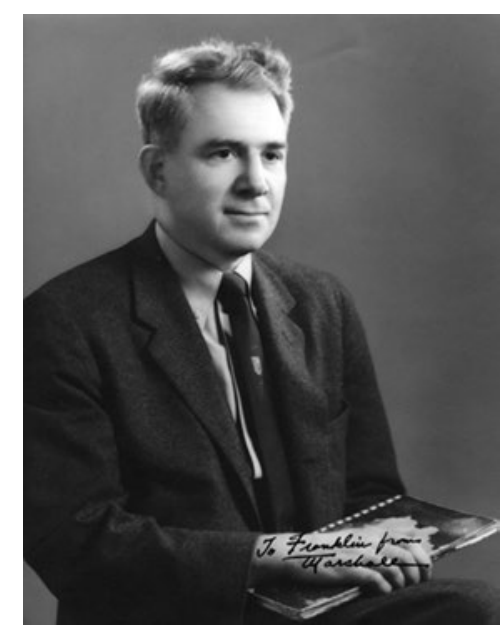

Figura 1. Marshall R. Urist, Physiology professor at the University of Chicago. In the Legend: To Franklin from Marshall. Reproduced with permission from: University of Chicago Photographic Archive, (apf108454), Special Collections Research Center, University of Chicago Library.

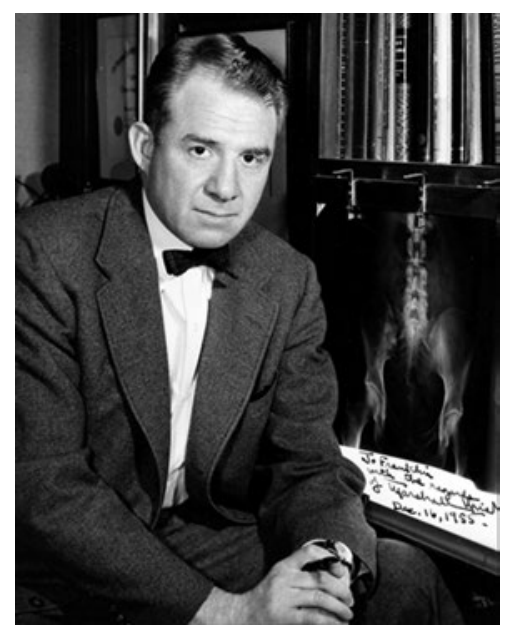

Figure 2. Marshall R. Urist, member of the Faculty of Medicine of the University of California at Los Angeles (UCLA). In the legend: To Franklin with the regards of Marshall Urist, December 16, 1955. Reproduced with permission from University of Chicago Photographic Archive, (apf1-08455), Special Collections Research Center, University of Chicago Library.

Instructor and Research Associate in the Department of Physiology, with his mentor and friend Professor Frank C. McLean ${ }^{14-17}$ (Fig. 1).

In 1948 he moved to California to establish his academic practice, where he would begin his research about the effects of estrogen on bone ${ }^{18,19}$, to later join as a clinical assistant professor, with the support of Dr. Stafford Warren, dean of the newly formed School of Medicine at UCLA. There, he was appointed Faculty Associate Professor in 1954, and then Professor of Orthopedic Surgery in $1969^{14,15}$ (Figs. 2 and 3).

Urist maintained a close relationship with Franklin McLean, of the University of Chicago, until the death 


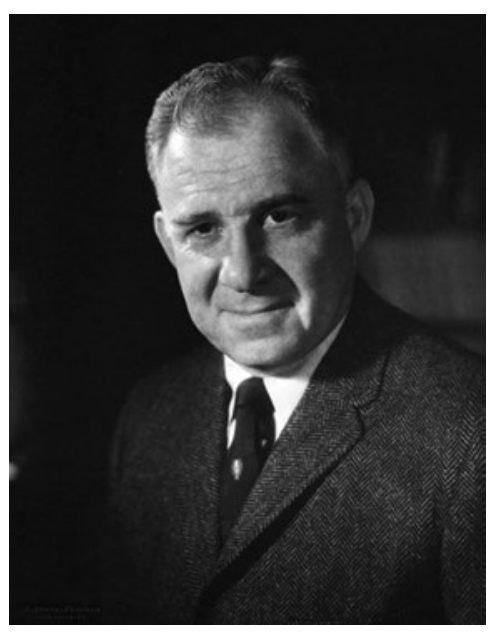

Figure 3. Marshall R. Urist, member of the Faculty of Medicine of the University of California at Los Angeles (UCLA). Reproduced with permission from University of Chicago Photographic Archive, (apf1-08456), Special Collections Research Center, University of Chicago Library.

of his mentor in 1968. In 1950, Urist and McLean received the important AAOS basic research award (Kappa Delta Award), for their work on the effects of estrogen in bone formation ${ }^{20,21}$.

Together with Franklin McLean, Urist published three successful editions (1955, 1961 and 1968) of the book entitled "Bone: An Introduction to the Physiology of Skeletal Tissue" in the Chicago University Press, within the editorial series The Scientist Library: Biology and Medicine ${ }^{22,23}$. At UCLA, contracted by the US Atomic Energy Commission, at the US Veterans Hospital, Urist started his investigations on the treatment of osteosarcoma with strontium 90-marked tetracycline. Also at UCLA, he founded a specific laboratory for bone research (Bone Research Laboratory at UCLA), better known as "The Bone Lab", a place that soon would turn into a center of scientific and intellectual exchange ${ }^{24}$.

However, his main line of investigation was bone growth physiology, where one of his works, published in Science in 1965 and entitled "Bone: Formation by Autoinduction", outlined the existence of bone-inducing substances ${ }^{25}$. According to the ORS, this work is now regarded as the start of the research on bone growth ${ }^{26}$. In fact, the US National Institute of Health Research classified it as a crucial point of contribution to science ${ }^{26}$.

In 2008, Dr. Richard A. Brand, who was then chief editor of the Clinical Orthopedics and Related Research journal, mentioned that, since 1953, Marshall R. Urist emphasized on the phenomenon of induction, in addition to arguing that the importance of the physiological phenomenon lied in the physical-chemical effect one tissue exerts on another when both get in touch ${ }^{27,28}$. Brand also mentioned that Urist postulated that induction appeared to be a much more complex mechanism than the direct humoral effect of a diffusible chemical substance, and that, in addition, isolation or characterization of inductor substances from extracts had not been yet satisfactorily achieved, and that probably it would not be possible doing it until knowledge on the process of endochondral ossification and endosteal bone formation was obtained from scientific experiments ${ }^{28}$.

Urich was right, and a serie of research works carried out by himself and his team led to the discovery and isolation of growth factors that were named $\mathrm{BMP}^{29-33}$. One work in particular, currently considered to be a "scientific classic" by the Clinical Orthopedics and Related Research journal, entitled "A morphogenetic matrix for differentiation of cartilage in tissue culture", allowed Urist to discover demineralized bone matrix morphogenetic properties, where he reported that they act as growth factors for bone stimulation and selective formation in different tissues ${ }^{31,32}$. Until that moment, in vitro-cultured skeletal tissues, as embryonic organs, were only known to be predestined or pre-differentiated towards specific tissues (e.g., cartilage or fibrous tissue), in the absence of postnatal mesenchymal cells differentiation induction, in spite of changes made in the composition of cell growth media; i.e., chemical changes only induced modifications on cell metabolism, but not on their specific tissue differentiation line.

Another study published by Urist in 1970 in a supplement of the Calcified Tissue Research journal entitled "A morphogenic matrix for differentiation of bone tissue", he reported the local extrinsic requirements in order for post-fetal mesenchymal cells to carry out bone morphogenesis ${ }^{29,30}$. In an additional work, dated in 1971 and published in Journal of Dentistry Research, entitled "Bone Morphogenetic Protein", Urist mentioned the progresses in the research of morphogenetic proteins biochemical characteristics, including an appendix with theoretical concepts and related terminology 33 . Both works were reprinted as classical texts by Clinical Orthopedics and Related Research in 2009 ${ }^{30,34}$. Urist, in "Bone Morphogenetic Protein", reported the ultrastructural characteristics of a processed demineralized bone matrix, where he noted that $3 \%$ of the dry, fat-free tissue occupied one third of the matrix domain; also, that these constituents included large proteoglycan molecules with attachments to collagen fibrils that were stained with bismuth nitrate, in addition to noting an interesting hypothesis on bone and bone marrow development in implants of matrix residues (deriving from enzymatic cleavage, chemical extraction or organic 
blockage procedures), where he suggested that morphogenetic bone activity resided in an interfibrillar macromolecular protein complex ${ }^{33,35}$.

Urist continued with his investigations on bone induction, but it was until 1983 that he published, again in Science, his work entitled "Bone Cell Differentiation and Growth Factors: Induced Activity of Chondro-osteogenic DNA"36. This work enabled finding the protein substances with osteoinductive and skeletal differentiation inductor capacity, which make up the family of BMPs. In his work, Urist concluded that both bone generation and regeneration are attributed to BMP efficiency and to bone-derived growth factors ${ }^{36}$. Owing to this hypothesis and his findings, Marshall Urist was included in the list of nominees to the Nobel Prize of Medicine and Physiology in $1991^{24}$.

With these works, the road towards the use of BMPs had been traced, since they contributed with the concept of "bone induction" to medical science ${ }^{37,38}$. This concept emerged from the implantation of known amounts of allogeneic, freeze-dried and demineralized bone matrix in animal muscle tissue, to then, based on this animal model, give way to investigations on bone induction physiology and biochemistry ${ }^{38-40}$ until it was demonstrated in 197041. The term "bone morphogenetic protein" (BMP) was introduced in 1971 to refer to a natural molecule of protein origin as bone morphogenesis inductor ${ }^{33}$. In the decades of 1980 and 1990, the first human morphogenetic proteins were managed to be purified ${ }^{42-46}$ and isolated $\mathrm{d}^{45,47}$.

Urist scientific work was prolific, with up to 486 articles on the subject being found using the PubMed literature search engine, in addition to imparting around 200 conferences throughout the world. Owing to his work and discoveries, Urist received different honors and scientific awards, such as a second AAOS Delta Kappa Award for his work published in Science in 1983, the Claude Bernard medal, a Fellowship granted by the John Simon Guggenheim Foundation and the Bristol Myers/Squibb Zimmer Distinguished Achievement Award for his achievements in orthopedics research. He received an honorary degree in medicine by the Lund University in Sweden, a honorary Fellowship by the Royal College of Surgeons of Edinburgh, he was active member and chairman of the Association of Bone and Joint Surgeons (ABJS), he obtained a honorary membership of the Japanese Orthopedics Association, and was chairman of the Society of International Research in Orthopedic Surgery and Traumatology and of the Hip Society of the USA. He also served as second chief editor of the prestigious orthopedics journal Clinical Orthopedics and Related Research from 1966 to 1993. As of 1996, the ORS and the ABJS instituted the "Marshall R. Urist Award", sponsored by the Journal of Orthopedic Surgery with a purse of US $\$ 5,000$ and a commemorative plaque, granted by the Wiley Blackwell publishing house, with the award ceremony taking place during the ORS meeting ${ }^{48}$. This award is intended to acknowledge all those who have established themselves as cutting-edge researchers in the area of tissue regeneration, doing it with a sustained ongoing scientific body, supported by research with clinical applications and focused on the area of tissue regeneration as it relates to the musculoskeletal system ${ }^{48}$.

Urist remained active in UCLA until his death on February 4, 2001, at the age of 86 years. According to a note published on February 7, 2001, in UCLA Newsroom news in its Health+Behavior section, the then dean of the School of Medicine and Medical Science rector, Dr. Gerald S. Levey, mentioned that Urist had dedicated his life to orthopedics, also that many advances in the field had been the result of his work and clinical research, and that that day of his death they had lost a great physician and scientist ${ }^{49}$.

On that same year, Dr. Rüdiger von Versen, then chief editor of the Cell and Tissue Banking journal, mentioned that Urist's sense about what was correct and adequate, as well as his capability to think in the broadest context, always safeguarded his reliable judgement, an addition that he possessed an energy and capacity to consistently raise and maintain enthusiasm until the end ${ }^{15}$. In 2009, Richard Brand, then editor of the Clinical Orthopedics and Related Research journal, decided to publish a symposium entitled "Symposium: Tribute to Dr. Marshall Urist: Musculoskeletal Growth Factors"50, where, in addition to his picture on the front page of the volume, a brief biography was included, as well as three of the aforementioned articles considered to be the most important ${ }^{30,32,34}$ (Fig. 4).

Perhaps there are few praises or recognitions left to be added for the war hero, writer, researcher, orthopedist physician, professor, academician, pioneer and human being; however, I think it is necessary getting to know him, through this biography, in the Ibero American community in pour language, to this way join, by the subjects competing us, to the recognition of his work and scientific legacy at more than 100 years of his birth. As once said German playwright Bertholt Brecht in a song entitled "In Praise of the Fighters", composed in 1931 for the play "The Mother", "There are men who struggle for a day and they are good. 


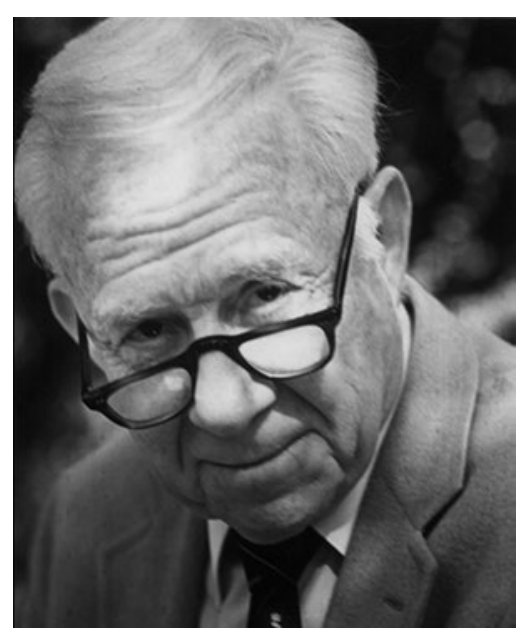

Figure 4. Prof. Dr. Marshall R. Urist (1914-2001). Picture included on the cover of Clinical Orthopaedics and Related Research, 2009, volume 467, No. 12, dedicated to his life, investigations and contributions. Reproduced with authorization of Springer Customer Service Centre GmbH: Springer, Clinical Orthopaedics and Related Research, Marshall R. Urist, 1914-2001, Brand RA, COPYRIGHT 2017.

There are men who struggle for a year and they are better. There are men who struggle many years, and they are better still. But there are those who struggle all their lives: Those are the indispensable ones".

\section{References}

1. Bick EM. American orthopedic surgery: the first 200 years. Bull $N$ Y Acad Med. 1976:52:293-325.

2. Eckardt JF. Historical notes. Marshall R. Urist, M.D. 1914-2001. UCLA/ Orthopaedic Hospital. Department of Orthopaedic Surgery. Alumni Bulletin 2014. p. 5-6.

3. Urist MR. The Journal of NIH Research 1997;9(1-6).

4. Urist MR. Bone morphogenetic protein: the molecularization of skeletal system development. J Bone Min Res. 1997;12:343-6.

5. Finerman GA. Marshall R. Urist, MD: 1914-2001. J Bone Joint Surg Am. $2001 ; 83: 1611$.

6. Urist MR, Ries L, Quigley TB. Improved methods of management of compound fractures of leg. US Army Med Dept Cull. 1947;7:396-8.

7. Urist MR. Injuries to the hip joint. Traumatic dislocations incurred chiefly in jeep accidents in World War II. Am J Surg. 1947;74:586-97.

8. Rogers WA. Book reviews. Surgery in World War II. Orthopaedic surgery in the European theater of operations. Mather Cleveland, M.D. Washington, Office of The Surgeon General, Department of the Army, 1956. J Bone Joint Surg Am. 1957;39:477-8.

9. Urist MR. The management of battle-incurred compound fractures in the region of the hip joint (The Wellcome Award Essay, 1947). Mil Surg. 1947;101:467-89.

10. Urist MR, Ries L, Quinley TB. A plaster traction splint for compound comminuted fractures of the tibia and fibula. Surgery. 1948;23:801-5.

11. Urist MR. Fractures of the acetabulum. The nature of the traumatic lesions, treatment, and two year end results. Ann Surg. 1948;127:1150-64.

12. Urist MR. Fracture dislocation of the hip joint. The nature of the traumatic lesion, treatment, late complications and results. J Bone Joint Surg. 1948;30:699-727.

13. Urist MR, Quingley TB. Use of skeletal traction for mass treatment of compound fractures. A summary of experience with 4290 cases during Worl War II. AMA Arch Surg. 1951;63:834-44.

14. Reiddi H. Marshall R. Urist: a renaissance scientist and orthopaedic surgeon. J Bone Joint Surg. 2003;85-A(Suppl 3):3-7.

15. Von Versen R. In Memoriam Marshall R. Urist (1914-2001). Cell Tissue Bank. 2001;2:185-6.

16. Brand RA. 50 years ago in CORR. Physiologic basis of bone-graft surgery. Marshall R. Urist MD. CORR 1953;1:207-216. Clin Orthop Relat Res. 2008;466:2015-6.

17. Finerman G. Marshall R. Urist MD, orthopaedic surgery: Los Angeles 1914-2001 professor. Universisty of California In Memoriam; 2001.
18. Urist MR, Budy AM, McLean FC. Factors influencing the reaction of the mammalian skeleton to estrogens. Trans Con for Metabolic Aspects of Convalescence. 1948;17:79-105.

19. Urist MR, Budy AM, McLean FC. Species differences in the reaction of the mammalian skeleton to estrogens. Proc Soc Exp Biol Med. 1948;68:324-6.

20. Urist MR, Budy M, McLean FC. Endosteal-bone formation in estrogen-treated mice. J Bone Joint Surg Am. 1950;32:143-62.

21. Delta-Kappa Award. AAOS 1950. Disponible en: http://www.aaos.org/ research/committee/research/Kappa/kappa_winners.asp\#1950

22. Crelin ES. Book review. Bone: an introduction to the physiology of skeletal tissue. Yale J Biol Med. 1961;34:150.

23. Brash JC. Book review. Bone. An introduction to the physiology of skeletal tissue. Journal of Anatomy. 1956;90(Pt 1):155-6.

24. Greenwald SA, Heim $\mathrm{C}$, Reddi $\mathrm{H}$, et al. The American Academy of Orthopaedic Surgeons. Section C. Academy News. The 2004 Annual Meeting Edition of the AAOS Bulletin. Today's News. Thursday, March 11, 2004. Profile of Orthopaedic Accomplishment: Marshall R. Urist, MD. Disponible en: http://www2.aaos.org/acadnews/2004news/c11-4.htm.

25. Urist MR. Bone: formation by autoinduction. Science. 1965;150:893-9.

26. ORS. Marshall R. Urist, MD Award. Disponible en: http://www.ors.org/ blog/2000/11/21/urist-award.

27. Urist MR. Physiologic basis of bonegraft surgery. Clin Orthop Relat Res. 1953;1:207-16.

28. Brand RA. 50 years ago in CORR: physiologic basis of bone-graft surgery. Marshall R. Urist MD CORR 1953;1:207-216. Clin Orthop Relat Res. 2008;466:2015-6.

29. Urist MR. A morphogenetic matrix for differentiation of bone tissue. Calcif Tissue Res. 1970;(Suppl):98-101.

30. Symposium: Tribute to Dr. Marshall Urist: Muskuloskeletal growth factors. The classic: A morphogenetic matrix for differentiation of bone tissue. Marshall R. Urist MD. Clin Orthop Relat Res. 2009;467:3068-70.

31. Nogami H, Urist MR. A morphogenetic matrix for differentiation of cartilage in tissue culture. Proc Soc Exp Biol Med. 1970;134;530-5.

32. Symposium: Tribute to Dr. Marshall Urist: Muskuloskeletal growth factors. The classic: A morphogenetic matrix for differentiation of cartilage in tissue culture. Hiroshi Nogami and Marshall R. Urist, MD. Clin Orthop Relat Res. 2009;467:3051-5.

33. Urist MR, Strates BS. Bone morphogenetic protein. J Dent Res. 1971;50:1392-406.

34. Symposium: Tribute to Dr. Marshall Urist. Musculoskeletal growth factors. The classic: Bone morphogenetic protein. Marshall R. Urist MD, Basil S. Strates. Clin Orthop Relat Res. 2009;467:3051-62.

35. Brand RA. Symposium: Tribute to Dr. Marshall Urist: Musculoskeltal Growth Factors. Marshall R. Urist, 1914-2001. Clin Orhtop Relat Res. 2009;467:3049-50.

36. Urist MR, DeLange RJ, Finerman GAM. Bone cell differentiation and growth factors: induced activity of chondro-osteogenic DNA. Science. 1983;220:680-6.

37. Urist MR. Bone: formation by autoinduction. Science. 1965;150:893-9

38. Urist MR, Silverman BF, Buring K, etal. The bone induction principle. Clin Orthop. 1967;53:243-83.

39. Dubuc FL, Urist MR. The accessibility of the bone induction principle in surface-decalcified bone implants. Clin Orthop. 1967;55:217-23.

40. Urist MR, Dowell TA, Hay PH, et al. Inductive substrates for bone formation. Clin Orthop. 1968;59:59-96.

41. Huggins $C B$, Urist MR. Dentin matrix transformation: rapid induction of alkaline phosphatase and cartilage. Science. 1970;167:896-8.

42. Sampath TK, Reddi AH. Dissociative extraction and reconstitution of extracelular matrix components involved in local bone differentiation. Proc Natl Acad Sci USA. 1981;78:7599-603.

43. Urist MR, Sato K, Brownell AG, et al. Human bone morphogenetic protein (hBMP). Proc Soc Exp Biol Med. 1983;173:194-9.

44. Urist MR, Huo YK, Brownell AG, et al. Purification of bovine bone morphogenetic protein by hydroxyapatite chromatography. Proc Natl Acad Sci USA. 1984;81:371-5.

45. Wozney JM, Rosen V, Celeste AJ, et al. Novel regulators of bone formation: molecular clones and activities. Science. 1988;242:1528-34.

46. Luyten FP, Cunningham NS, Ma S, et al. Purification and partial amino acid sequence of osteogenin, a protein initiating bone differentiation. J Biol Chem. 1989;264:13377-80.

47. Reddi $\mathrm{AH}$. Bone morphogenetic proteins: an unconventional approach to isolation of first mammalian morphogens. Cytokine Growth Factor Rev. 1997;8:11-20.

48. Marshall R. Urist Award. Disponible en: http://www.ors.org/blog/2000/11/21/ urist-award/

49. Everly A. UCLA Newsroom Health+Behavior. Prominent orthopaedic surgeon Dr. Marshall Urist dies; taught and practiced medicine at UCLA since 1954. February 07, 2001. Disponible en: http://newsroom.ucla.edu/ releases/Prominent-Orthopedic-Surgeon-Dr-2124

50. Symposium: Tribute to Dr. Marshall Urist: Musculoskeletal Growth Factors. Clinical Orthopedics and Related Research. December 2009, Volume 467, Number 12, Copublished by Springer International Publishing AG with The Association of Bone and Joint Surgeons. ISSN: 0009-921X (Print) 1528-1132 (On Line). 